\title{
The Lyford Model of Classroom Management: Authentication through Continuing "Reflections from the Field"
}

\author{
Gordon Lyons' ${ }^{1}$ Michael Arthur-Kelly', Margot Ford ${ }^{2}$ \\ ${ }^{1}$ Centre for Special Education and Disability Studies, University of Newcastle, Newcastle, Australia \\ ${ }^{2}$ School of Education, University of Newcastle, Newcastle, Australia \\ Email: Gordon.lyons@newcastle.edu.au
}

Received 14 August 2015; accepted 16 November 2015; published 19 November 2015

Copyright (C) 2015 by authors and Scientific Research Publishing Inc.

This work is licensed under the Creative Commons Attribution International License (CC BY). http://creativecommons.org/licenses/by/4.0/

(c) (i) Open Access

\section{Abstract}

The Lyford model of classroom management was first published as the centrepiece of an Australian undergraduate classroom management textbook in 2011. It was conceptualised and developed by the text authors, drawing on a qualitative analysis of their professional experiences, knowledge, beliefs and understandings. Consequently additional data were sought to test the legitimacy and rigour of the model. Each year the first author has called for "Reflections from the field": short stories written by practicing teachers explaining what they understood their theoretical and practical approaches to classroom management were in their various teaching contexts. Over six years 54 stories have been gathered and progressively analyzed using a qualitative grounded theory approach. This very rich and growing source of data has consistently delivered substantial evidence supporting the authenticity and utility of the model. The model has "stood the test of time" in that it continues to both accommodate and embrace the evolving positions of the authors, and also of a growing number of exemplary practicing teachers. This paper commences with an introduction into the authors' views on classroom management as a context for then describing and explaining the Lyford model, and the grounded theoretical process by which it comes to be. The continuing data source: the positions put by a growing number of practicing classroom teachers; is then described, followed by a brief explanation of the continuing grounded theoretical process of analysis. To illuminate this analysis, extracts are included from selected "Reflections from the Field", with analytic breadth coming from a diversity of smaller extracts, and scope coming from one full Reflection. The authors then discuss various points of interest emerging from this continuing analysis, including suggestions to academic peers around teaching classroom management, and suggestions to their pre-service and early service colleagues around doing classroom management. 
Keywords

Classroom Management, Lyford Model, Grounded Theory, Praxis, Teaching Philosophy

\section{Introduction}

Educational philosophies, theories, models, principles and practices are diverse but every teacher should be able to articulate their professional philosophy, theoretical approach to classroom management, and preferred model of classroom management (Lyons, Ford, \& Slee, 2014) notwithstanding their often dynamic and evolutionary nature (Porter, 2007). This capacity is central to being a reflexive and empowered practitioner (Henley, 2006). Classroom management is one aspect of pedagogy that often challenges even the most experienced and accomplished teachers (BOSTES, 2014; Killen, 2012) and indeed the profession is sadly littered with the resignations of defeated teachers. Some studies have indicated that up to one third of Australian early career teachers soon leave the profession because of undue pressure significantly contributed to by poor student behaviour (Buchanan, 2013; Ewing \& Manual, 2005).

Australian teacher education programs are required to include a course of study on "special education" (Foreman \& Arthur-Kelly, 2014) but not on classroom management (BOSTES, 2014; Gore \& Parkes, 2008). There is mounting political, professional and community concern over the increasingly challenging behaviours of school students of all ages at a time of additional demands on classroom teachers. Pressure is therefore mounting both from pre-service teachers and the education field more broadly for stand-alone courses on classroom management (BOSTES, 2014; Michail, 2011). Teachers need access to an authentic, flexible and facilitative model of classroom management, and this access best commences at the pre-service stage of their career (O’Neill \& Stephenson, 2014). A great deal has been written about student behaviour and classroom management, with high demand for evidence-based professional development resources and learning opportunities at the pre-service and in-service levels (Arthur-Kelly, Sutherland, Lyons, \& Foreman, 2013; Jones \& Jones, 2013).

Current theorising favours a focus on the development of systemic (school wide) preventative and developmental approaches to student behaviour rather than disciplinary approaches targeting individual students in the classroom (Childs, Kincaid, George \& Gage, 2015). The Lyford model is a flexible framework that pre-service and early career teachers can use to scaffold their own classroom management plans, which takes account of school wide practices, their own classroom management approach and the needs of individual students. Furthermore the model allows educational practitioners to take account of the socio-cultural context in which students operate as an important element within the broader context of classrooms and schools. The Lyford model is designed to create a classroom management plan that has internal integrity between teaching philosophy, theoretical approaches to classroom management and practice (Manning \& Butcher, 2013). This paper begins with an explanation of the Lyford model (the Model), and the collaborative-grounded theoretical process that led to its development.

\section{The Lyford Model}

To preface the following description and explanation of the Model, two figures (Figure 1 and Figure 2) from Lyons, Ford, \& Arthur-Kelly, 2011: p. 4 \& 9 are included (reprinted with permission).

The Model offers a dynamic approach to individual teacher's relationships, processes and classroom management principles, theories and practices, in other words, "praxis", taking as its core understanding the need to create an environment where all children feel they belong and where teachers thrive. It is not a personal theoretical approach to classroom management, but a mechanism and process for bringing synchronicity, cohesion and "life" to praxis.

Five principles underpin this model, first, which positive learning environments (in classrooms and (pre) schools) should be developed through an ecological lens, informed by the seminal work of Bronfenbrenner (1979). Second, that all pedagogy should be evidence-based (Odom et al., 2005). Third, that classroom management is an integral part of everything else that functions in learning environments to promote student engagement and learning (Gore \& Parkes, 2008; Jones \& Jones, 2013). Fourth, that classroom management should be essentially proactive and positive rather than reactive and negative (See Brophy, 1999; Kounin, 1970). Fifth, 


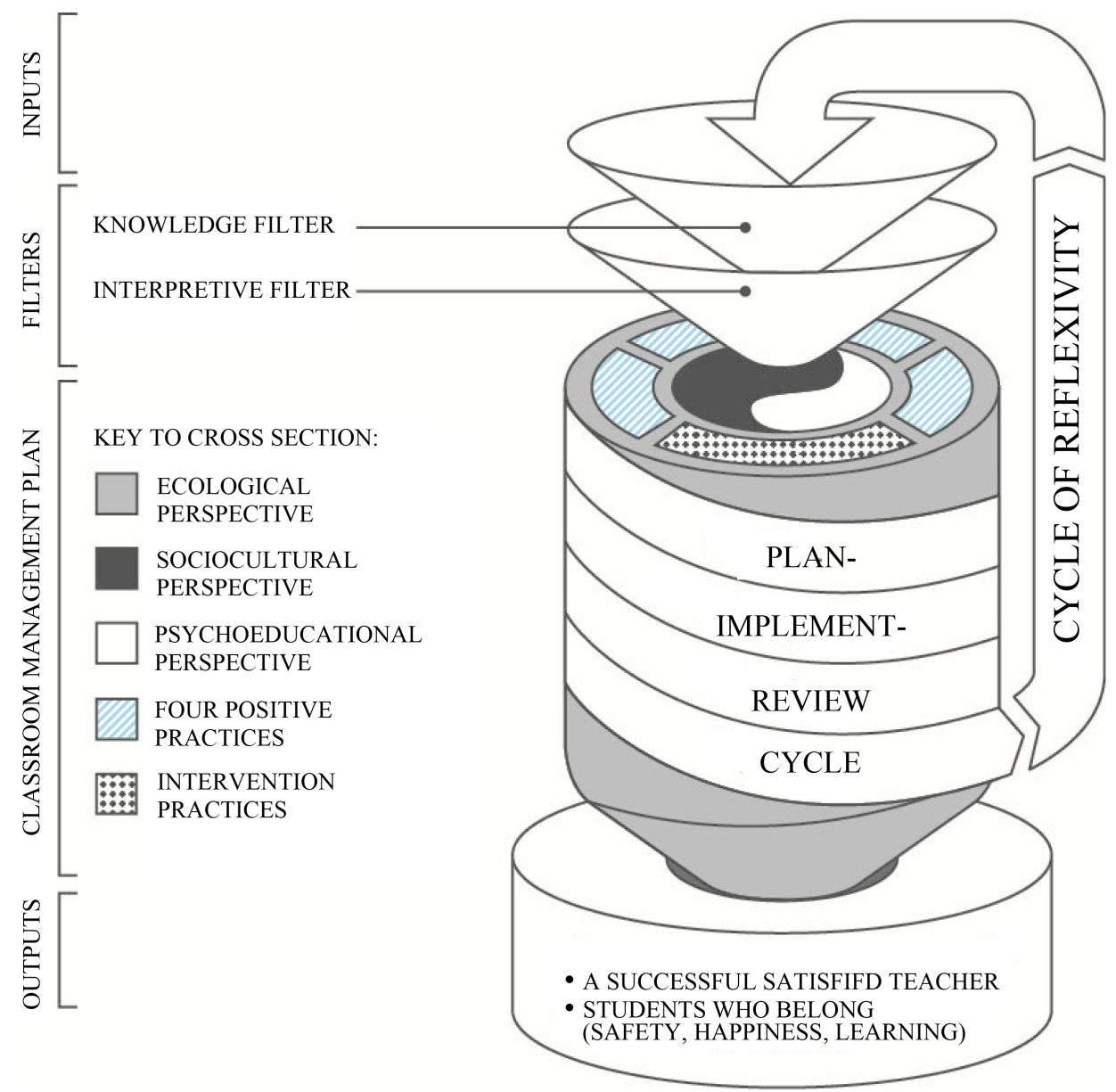

Figure 1. The Lyford model.

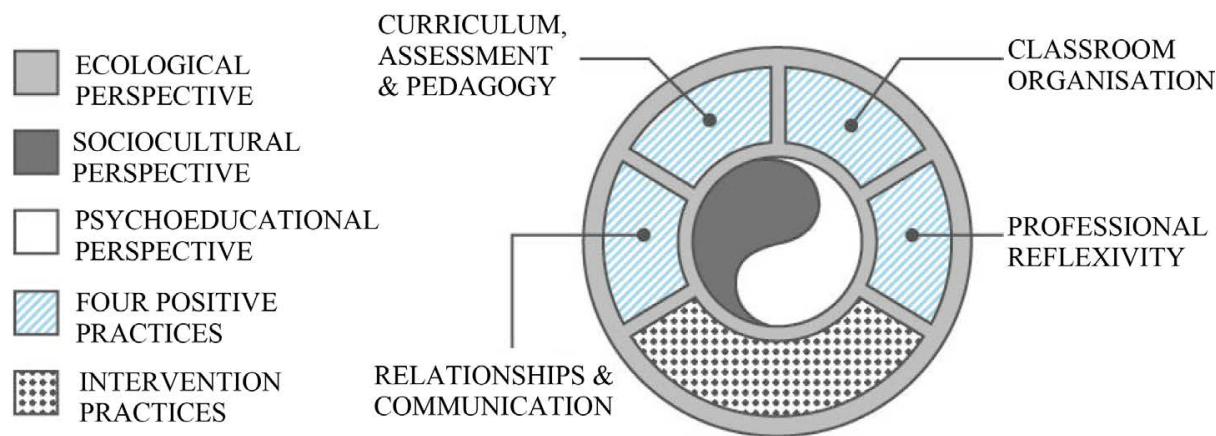

Figure 2. The Lyford model-a cross-section.

that the development of classroom management knowledge, skills and practices is a dynamic process, and continues throughout a teacher's career (Day, 1999; O’Neill \& Stephenson, 2014).

The Model has four main parts: Inputs, Filters, a Classroom Management Plan and Outputs. The Inputs include knowledge and understanding of classroom management and pedagogy; precipitated out of a continuing cycle of professional reflexivity. The Filters include a knowledge filter and an interpretive filter wherein new knowledge and hence understanding is filtered through old information bases and adapts accordingly. The Plan is built around a core ecological perspective and synchronistic sociocultural and psychoeducational perspectives: perspectives that enable practitioners to make sense of individual behaviours within a broader social context. The Plan also includes four positive practices (relationships and communication; curriculum assessment and 
pedagogy; classroom organisation; and professional reflexivity) and intervention practices. The Plan is dynamic and driven synergistically by a cycle of reflexivity and the "plan-implement-review" cycle. Ultimately the Classroom Management Plan, if authentically constructed and maintained, and designed in line with the overarching systemic plan, delivers the Outputs of a successful, satisfied teacher and students who belong and are safe, happy and learning effectively.

The Model is not prescriptive of philosophy, perspective, theory or pedagogy, but it does require the individual teacher to give consideration to all these elements-just like other evidence-based models of best practice like the NSW Model of Quality Teaching (Ladwig, 2009) and Authentic Teaching (Newman et al., 1996). The development of the Model itself was an eclectic act, informed and influenced by a range of theories broadly pertinent to classroom management. This range included, variously: humanist theories, knowledge acquisition theory, ecological systems theory, sociocultural theory, psychoeducational theory and cognitive behavioural theory. (For details see: Theories underpinning the Lyford Model. available@ https://cengage.com.au/).

\section{Developing the Model: Collaborative Consultation}

In developing the Model, the authors, who come from diverse philosophical, theoretical and professional backgrounds, spent a great deal of time robustly discussing the philosophies, principles and theories which would underpin their preferred collaborative model of classroom management. The aim from the outset was to create a model that contained ways that pre-service and neophyte teachers could create a dynamic classroom management plan, taking account of a variety of important elements. The authors understood that perspectives from a cognitive behaviourist influence needed to be integrated with perspectives from socio-cultural influences, because individual agency and action needs to be understood within a socio-cultural context. Underpinning the connection between diverse views was the notion of "belonging", an element that emerged from both traditions.

Because the model is not prescriptive, it does allow for quite different and even opposing ideas to be inculcated into a variety of classroom management plans. For example, one of the authors remains a strong advocate for "lollies stamps and stickers", whilst another shudders at the thought of teachers using "crude extrinsic material bribes". The point is the Model allows for different approaches and strategies as long as they can articulate into a coherent approach that reflects a particular set of theories and philosophical positions. Therefore, the focus and flow of discussions, over many hours, centred first on establishing an agreed set of broad principles. Repeated use of the hypothetico-deductive spiral strategy (Godfrey-Smith, 2003) and many challenging excursions into inductive and deductive collaborative analyses ultimately delivered these.

We then looked to building a model rather than "just" another theory; of which there were already many in the extant literature (see Manning \& Bucher, 2013; Porter, 2007). Our focus was on developing a model that could accommodate, integrate and synergise a range of personal teaching/learning philosophies (perspectives) (a "scaffold" of a model if you will) and at the same time deliver process and outputs embedded in a Cycle of Reflexivity (Grundy, 1995). One important aspect of the Model takes account of criticism that classroom management sits on the periphery of teaching and learning the curriculum (Gore \& Parkes 2008). In this model classroom management becomes an integral part of the teaching-learning nexus. This is echoed in the use of the traditional plan-implement-review cycle. Ultimately we sought to deliver a "transformational" model, which could be adapted to accommodate the developmental changes in theorising and pedagogy that typified professional development for teachers as they progressed through the pre-service, early, mid and late stages of their career. There was at this early stage no designed "structure" to this discussion; it emerged organically with consensus and agreement evolving, despite the divergent views "around the table". An exercise that brings educators together from very divergent viewpoints can only occur when there is deep respect and robust collegial rapport.

The original data: the professional knowledge, understandings and experiences of the three authors, derived through extended collaborative discussion, was then more robustly analysed using grounded theory methodology and research methods, an approach very familiar to the first author.

\section{Developing the Model: Grounded Theory Methodology and Methods}

The development of the Model adopted interpretism as its inquiry paradigm using modified "Straussian" Grounded Theory (Denzin \& Lincoln, 2005; Charmaz 2006). Co-construction recognises multiple realities from individual vantage points (Hatch 2002). Discussion, note taking and diagramming were the primary means to articulate and develop consensus and new understandings. Figure 3 presents a graphical explanation of this 


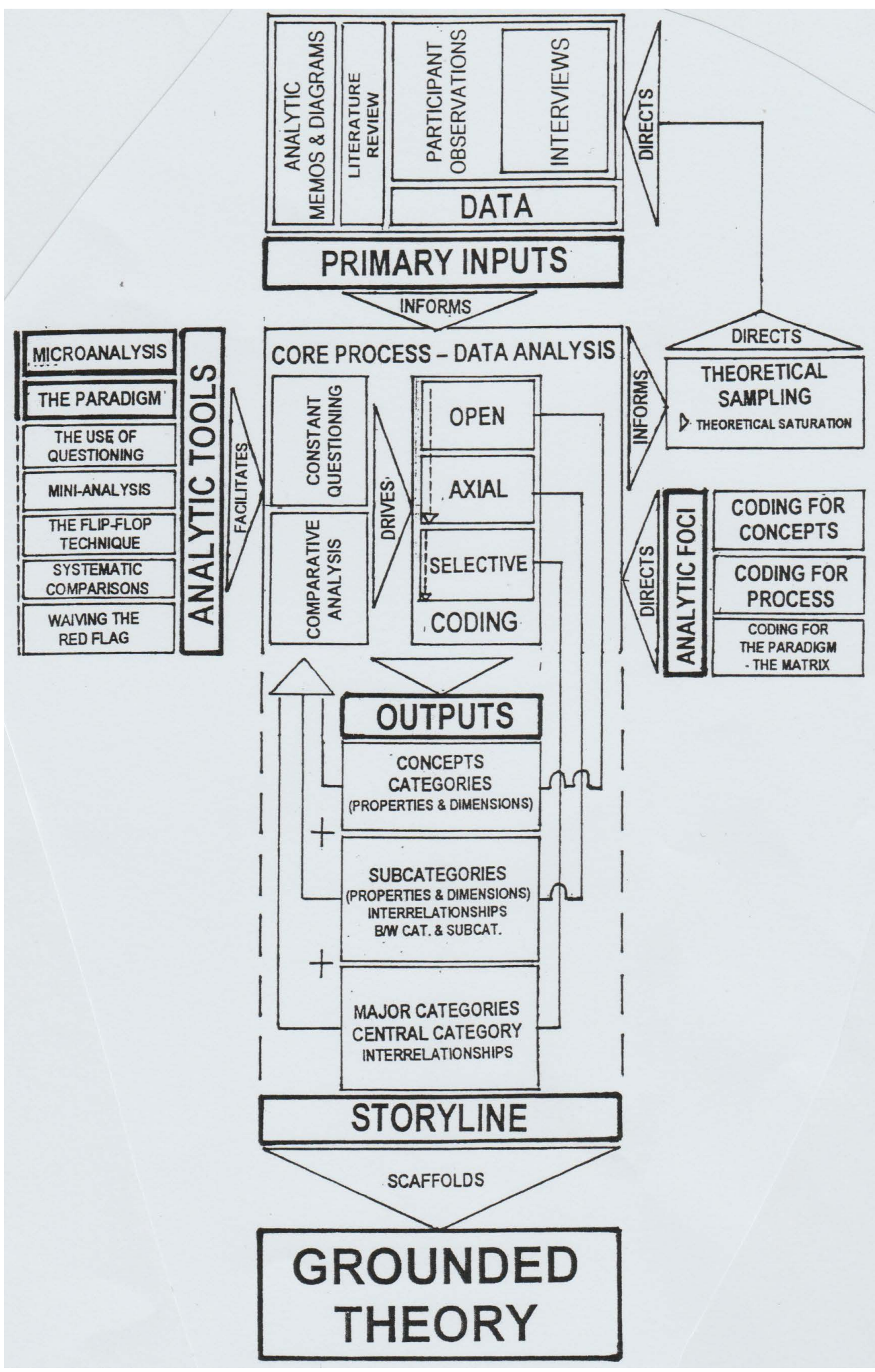

Figure 3. Modified Straussian grounded theory.

modified Straussian Grounded Theory that informed the analysis of data, followed by a brief explanation of the methodology and methods underpinning the data analysis and reporting. 
Grounded Theory is a research methodology that allows for both inductive and deductive reasoning. It seeks to generate new ideas grounded in evolving constructs that is rigorous and evidence-based. The process of grounded theory is non-linear, and directed by emerging relationships associated with progressive data analysis. In this case the focus remained on a continuing reflective and comparative analysis of discussions, field notes and diagrams that returned regularly to available evidence-based research. New understandings relating to the Model's authenticity and utility emerged out of interrogations from the often divergent influences of psychological perspectives, long the domain of traditional classroom management, and sociology, a relatively new influence in the field. In this instance the reflective capacities of the participants engaged in an examination of diverse theoretical perspectives is taken as an essential part of the discovery of new knowledge (Flick von Kardoff \& Steinke, 2004).

Our main analytic challenge was to identify connections between seemingly divergent theoretical paradigms, our ideological imprints and our collective understanding of classroom management practices "in the field", while at the same time periodically reflecting on our research methodology and methods (Johnson, 1998; Oliver, 1993). The Model emerged out of our expert differences and similarities, conflict and consensus, and philosophical devolution and evolution. Our collective epiphany was to recognize that this process of development utilized many elements of the emerging Model itself, a double hermeneutic, to take a term from sociology, reflexivity writ large. What we now had was a model of classroom management developed by three education academics; well grounded in consensus and balanced with professional knowledge and experiences. The next step was to "test" the application of the model so we sought out the understandings and positions of real practicing pre-service and neophyte early childhood, primary and secondary teachers.

\section{Reflections from the Field: The Data}

In order to interrogate the efficacy of the Model evidence was in the first instance sought from educators, not about the Model itself but about their theoretical approaches to and practices of classroom management. Secondly a data source was established from the professional knowledge, understandings and experiences of a strategic and growing set of practicing (pre) school teachers.

In preparation for the use of the Lyford model as part of a classroom management textbook (Lyons, Ford, \& Arthur-Kelly, 2011) sixteen short "stories" were written by early career primary and secondary teachers, who were variously employed in permanent full-time and temporary part-time positions in Government and nonGovernment schools. Many were former students of the University of Newcastle teacher education programs who had graduated within the previous two years. Three stories were written by pre-service teachers; one training to be an early childhood teacher, one a primary teacher and one a secondary teacher. Two stories were written by mid-career preschool educators, one a teacher and one a preschool Director.

Each writer was simply asked to write a short story describing and explaining, "how they would set up a class (group) at the beginning of the year". There was no request to specifically address their theoretical approach to classroom management, but it was noted that the authors would be constructing a follow-on Commentary on each story; focusing on the relevance of the story to the textbook content, including connections to the Lyford model. Each writer was credited in the textbook "Acknowledgements" and gave consent for the stories to be further analysed. At the time of writing none of the writers were aware of the Model; only that their stories were to be included in the forthcoming textbook and/or companion website. It should be noted that the authors had always intended that a chapter would be dedicated to such stories because it was the authors' collective view that case studies provided an invaluable richness to the learning experience (see also Anderson, 2005; Shulman, 1992). It was not anticipated that the stories would become such valuable data to be analyzed for the purposes of reflecting specifically and so closely on the Model itself. Their inclusion, in the 2011 textbook, was otherwise fortuitous and facilitative for this research project.

The selection of contributing writers for this chapter was strategic for its original purpose. All three authors had extensive collegial networks amongst former students and colleagues in the teaching profession. All three authors also taught into various undergraduate and post graduate teacher preparation and elective courses in special education so contributions were canvassed from high achieving past students who had already demonstrated strong teaching capabilities and performance in the field. In the 2014 edition of the textbook, (Lyons, Ford, \& Slee, 2014) which presented the Model for the second time, one chapter "Stories from the field" presented a selection of 10 short stories. 
Each year, since 2011, the first author has invited exemplary current and former students and other colleagues to submit their stories/reflections from the field for publication and analysis; more recently on the textbook companion website. These invitations were made strategically, primarily to hear from as wide a diversity of practicing (and pre-service) teachers as possible, and to maintain "currency" given the changing landscape of classroom management theory and practice. Although the pre-service writers had limited classroom teaching experience (often only eight weeks on supervised practicums) they were chosen because of the quality of their engagement in related coursework and outstanding results while on practicum. In total 54 stories/reflections have been collected and subjected to analysis, with a further 10 under invitation at the time of writing. As was originally the case, each writer invitee was simply asked to write a short (1000 word) story describing and explaining "how they would set up a class (group) at the beginning of the year".

\section{Reflections from the Field: A Continuing Grounded Theory Analysis}

The accumulating qualitative data (short stories delivered in narrative form by a diversity of invited practicing teachers) suited a continuing grounded theoretical analysis (Charmaz, 2006) of texts that describe life-worlds from the inside out and from the point of view of the writers (Denzin \& Lincoln, 2000; Flick, 2005). The authors were looking for evidence from "real" teachers that their Model of classroom management was relevant, authentic and useful.

Furthermore, the authors were interested to see if the Model (and its "categories" and "storyline") would be reflected in the classroom management practices of a variety of practicing teachers regardless of variables such as teaching settings, contexts and career stages. These variables included: pre, primary and high school teaching settings; full-time and part-time appointment conditions, and pre, early, mid and late career stages. A potential extra insight gained from including pre-service teachers as writers was that they might give more insightful feedback on how well they were understanding and embracing learning about classroom management generally, and from the Lyford model specifically.

\section{Reflections from the Field: Some Illustrative Extracts}

This section includes extracts from a selection of the early "Reflections from the Field". The extracts include the opening summary statement explaining the context for the story, and the closing Commentary written by the authors, explaining how that story relates to and reflects the content of the text. These provide some "breadth" to the sample data analysis. These are followed by one complete story (with its opening statement and closing Commentary), written by one practicing primary school teacher. This provides some "depth" to the sample data analysis. In each sample story the various references to the metalanguage of key elements (categories) and the storyline (processes) of the Lyford model are italicised to draw attention to its evidential nature. (These stories are published in the $3^{\text {rd }}$ and $4^{\text {th }}$ editions of the text (Lyons et al., 2011; 2014) and on the companion website.)

\subsection{Jenny}

Opening Context Statement: Jenny is an experienced early childhood professional who has taught in primary and adult education. Jenny's reflection explains her perspective on what constitutes a good (preschool) centre, and her philosophy on the "important ingredients" needed to make a smoothly managed centre.

Closing Commentary Statement: Jenny's explanation of the qualities of a good healthy childcare centre resonates with an ecological and sociological perspective. The building of positive relationships through effective communication is of central concern. Well-managed centres use key positive practices like constant reflection, quality curriculum and pedagogy and careful organisation. Staff are encouraged to respond to children's more difficult behaviours by using positive practices and, when necessary, psychoeducationally-based intervention strategies. The clear preference is to prevent rather than intervene. For Jenny, a positive learning environment is best demonstrated by good, productive, happy noise!

\subsection{Dina}

Opening Context Statement: Dina is a pre-service teacher in her final placement. She is in a childcare centre in the preschool room with an experienced supervising colleague teacher and a childcare assistant.

Closing Commentary Statement: Dina immediately emphasises the importance of communication and rela- 
tionships, and curriculum. She was trying to make sure all the children's needs were met. She felt that it was important that even if a child has behavioural issues, he or she still needed to be included in the group activities wherever possible; this was part of her philosophy of inclusion. Here, she looked at prevention measures, whereby the group as a whole understood the boundaries more clearly, but within a supportive structure. She also knew particular measures were required for one child and set up an intervention plan that the staff were willing to try. Importantly, Dina showed commendable initiative in communicating her observations and opinions to her colleagues and a substantial capacity for self-reflection and reflexivity.

\subsection{Shay}

Opening Context Statement: Shay was a fantastic first year primary-trained teacher who worked fulltime as a temporary teacher before moving to teach in London. Shay's first block appointment was a full Term 4 with "that notorious" Year 6 class. The focus of her story... was to introduce and establish a new approach to classroom management for an "entrenched" senior primary class.

Closing Commentary Statement: Shay's reflective description provides a plethora of viewpoints from which to examine the challenges and triumphs that await early career and experienced teachers under similar circumstances. Taking on and recovering an existing difficult class is one of the most difficult challenges for an experienced, let alone early career teacher. At least six key elements may be identified which contribute towards her success. First, Shay was well organised and prepared; enabling her to establish an organised classroom. Second, she made a concerted effort to get to know her students; enabling her to build and establish positive relationships and trust. An ecological perspective appears to have rationalised this decision. Third, she recognised the central relationship between achieving quality curriculum and instruction and her students' motivation to learn. Fourth, she continued to develop an organised classroom through the (collaborative) development of rules, expectations, guidelines and consequences. Fifth, in line with psychoeducational theory, she focused her continuing positive relationship building on developing the children's self-esteem and trust. Sixth, Shay was a reflective practitioner, and modified her practices based on her continuing reflections. Exemplary!

\subsection{Michele}

Opening Context Statement: Michele is a mature-aged primary-trained teacher who returned to casual teaching after an extended period of child rearing and home duties. Her reflection focuses on the pragmatics of establishing an effective learning environment as a day-to-day casual primary teacher.

Closing Commentary Statement: Michele's explanations of her principles for establishing a sound learning environment and facilitating learning as a day-to-day casual teacher highlights the dilemmas and challenges that so often face casual teachers; particularly those employed on a day-to-day basis. The pragmatic demand to get up and running within minutes of meeting with an unfamiliar class and/or commencing a day's work (or a lesson for casual secondary teachers) undoubtedly compromises the application of philosophies and lofty ideals. Nevertheless the elements of good teaching are surprisingly generic. It seems that the more a teacher knows about her or his students the easier it is to build positive relationships. Themore organised a teacher and classroom are, the better the behaviour and learning. This organisation is still evident in high standards, clear routines, and quality curriculum, materials and instructional strategies. Behaviour and learning are similarly enhanced when effective communication prevails. Timely reflection and review is still paramount to inform changes in curriculum and instruction. Individual interventions may still be necessary but will generally be pre-planned and use behaviourist strategies. Finally, key theories and approaches to classroom management are still pertinent, but the casual teacher may well have moved towards a more eclectic or behaviourist orientation. Michele's golden rule is to "keep lessons simple". This means she is very clear about her philosophy and approach to classroom management. She communicates this clearly and quickly to her students, and uses the same key preventative practices as successful full-time classroom teachers. Clearly though, emphasis and timing are more critical in this type of teaching.

\subsection{Rebecca}

Opening Context Statement: Rebecca is a very capable and enthusiastic undergraduate student in a primary teacher education program. Her reflection explains her professional philosophy, and the main elements of her 
emergent classroom management plan.

Closing Commentary Statement: Bec's story is a beaut example of an emerging professional philosophy and practical approach to classroom management. Clearly evident throughout her reflection are implicit and explicit references to the importance of relationships with students, classroom organization-behavioural standards, organisation and routines and procedures, and curriculum and pedagogy ("good kids are busy kids"). Although not explicit, Bec anchors her explanations on her underpinning philosophy and theoretical approach to classroom management.

\subsection{Lisa}

Opening Context Statement: At the time of writing this reflection, Lisa had just completed her training to teach secondary science. Lisa demonstrated an outstanding ability and potential in her internship at an outer suburban Sydney high school with a high proportion of disadvantaged and challenging students. She was so impressive that a nearby independent school, with a socio-economically-advantaged demographic, immediately offered her a term-long teaching block. For Lisa, this was an entirely different kettle of fish and held entirely different challenges! The focus of her reflection is to explain her professional philosophy as a pre-service and early career secondary science teacher.

Closing Commentary Statement: Lisa's story demonstrates a mature insight into the power that self-reflection has upon professional practice. Lisa offers an explanation of her philosophy of learning and teaching, and of how she tried to impart her inspiring enthusiasm to her students. Lisa's philosophy appears closely aligned to the psychoeducational school of theorists, and has an ecological perspective that emphasizes knowing and building positive relationships with her students, and a critical awareness of the need for achieving quality curriculum and instruction.

\subsection{Annie}

Opening Context Statement: At the time of writing this Annie was a first year (primary-trained) teacher who worked on a casual basis at her local senior high school, particularly supporting senior students with learning difficulties. (Annie graduated with first-class honours and was awarded a University Medal for her outstanding scholarship in the primary teacher education program.) The focus of her reflection is on managing and supporting learning of senior students, particularly those with learning difficulties, after newly graduating as a primary teacher!

Closing Commentary Statement: In an elegantly worded reflection, Annie offers the reader two valuable insights into her thinking as an early career teacher. One insight concerns the value of critical, professional self-reflection. Knowing oneself empowers the knowing of others. Annie emphasises this, particularly with respect to the development of classroom management practices that clearly, in her opinion, require the 'knowing' of others. The second insight concerns her beliefs about what works in classroom and behaviour management; particularly for beginning teachers. Annie articulates strong support for taking an ecological perspective. That is, to: "gain insight into the myriad and eclectic influences that impact on students" lives." Through acknowledging the primary connection between learning and good behaviour, she emphasises the importance of: achieving quality curriculum and instruction (well-planned and executed lessons); positive effective communication; establishing an organised classroom (a few simple rules about communication and attitude to learning); and again, being a reflective practitioner. Annie's personal philosophy is aligned towards the key theories underpinning the Lyford Model, particularly those viewed as psychoeducational.

\subsection{Wendy}

Opening Context Statement: Wendy is a final year student in a secondary (English) teacher education program. Her reflection focuses on the basics of classroom management, particularly as they apply to setting up a new class.

Closing Commentary Statement: Wendy succinctly sets out her professional philosophy and theoretical approach to classroom management. Being organised and planning carefully set the scene for quality assessment, teaching and learning. Positive relationships with students are central to this. Wendy has thought through the basics of her classroom management plan and shows clear insight into the issues and challenges, which face 
early career teachers. Wendy will be a very good teacher...

The abovementioned illustrative extracts were intended to provide some "breadth" to the sample data analysis. The next section provides one complete story (with its opening statement and closing commentary) written by Katie, an early career primary school teacher. This is intended to provide some depth to this sample data analysis.

\section{Reflections from the Field: A Complete Story}

\section{Katie}

Opening Context Statement: Katie is an outstanding early career teacher, qualified in both early childhood and primary teaching. She was recently appointed to a junior class at a government primary school in a mediumsized country town. Her reflection explains her philosophical approach to and how she built her classroom community-a safe haven wherein her students could learn and she could teach!

Katie's Story: I have just completed my first year of full-time paid teaching and what a rollercoaster of a journey! I accepted a position in a country town; approximately seven hours drive from home. Relocating was an expedition in itself, if you will pardon the pun, but it was nothing compared to the isolation and bureaucracy that was waiting for me. I was a tiny tadpole in a giant political pond (a story for another day) and had to make a decision. I could take the easy option-to stay and conform. (The school policies had been in place for over a decade and change was deemed "unnecessary".) I could jump ponds (so to speak) but maybe only to be eaten alive somewhere else. Alternatively I could embrace the cycle of change on my own terms and create pond ripples (within the letter of the law of course) in order to ensure I followed my dream. I chose the latter. You may scratch your head and ask why make changes? The answer is simple-I wanted to teach and to show that even "the new kid on the block" could actively and valuably contribute!

Throughout my training I was blessed with the teachings of some truly successful educators. These professionals were well grounded in their subject matter, dedicated to their students' learning and willing to experiment with different teaching strategies. They were always supportive of colleagues and respectful in their relationships with parents and community. I observed these people, absorbed their teachings, modelled myself on their behaviours and aspired to follow in their footsteps. I learned quickly that in the teaching profession there is no room for failure... you pick yourself up and change tactics constantly to achieve your objective-to help your students be their best.

So how did I make it through my first year? I focused my energy into building a classroom community where I could grow alongside my students. Building a classroom community provides the two elements every teacher seeks-student achievement and fewer behavioural problems. A classroom community isn't built overnight, but I quickly learned that construction begins during your first days of school.

Getting started was a challenge but incorporating a few basic strategies from the beginning really helped. It was important that I actively modelled civil discourse and appropriate classroom behaviours so that my students had a sense of how they should proceed. Using words and phrases like "Please", "Thank you" and "Excuse me" were a must. "May I help?”, "What a great idea!” and "Thanks for trying” were also useful. My rule of thumb in the classroom was (and still is) that I receive what I give.

Quality teaching was a must and I found a key component of this to be high expectations. Sharing my expectations for the class and asking students how everyone can help to achieve these was a great way of opening discussion. I explained to the students that my goal was to create a community that helps and supports each other so that our classroom was the best place to be. This led to implementing a simple set of classroom guidelines called the five Cs: Caring, Compassion, Courtesy, Carefulness and Common Sense. These five Cs would guide behaviours in our community.

The classroom meeting process was also introduced to share expectations and devise these guidelines. The most compassionate and empowered young critical thinkers I have ever had the privilege of meeting are those who engaged in classroom meetings. Our meetings built ownership in peer behaviours and developed problem-solving skills. Throughout the year whenever a challenge arose, I used this process to discuss with my students an appropriate resolution. Well run meetings took very little time, in fact once students were familiar with the process they were actually time savers.

A consistent classroom management system was required, as within any community, but it had to be one where students could take ownership and responsibility. I introduced a traffic light system into the classroom 
that aligned with the "Stop, Think, Do" motto in the school's personal development program. This saw each child having a traffic light on their desk with their name tag. The three colours of the traffic lights were used as behavioural reminders for the students. Each time a student was spoken to about behaviours falling outside our five Cs guidelines they would move their name tag up to the next Velcro dot on their traffic light. Each Velcro dot aligned with the traffic light colours which meant the act of moving the nametag catered for the students' visual, tactile and auditory senses. When a student reached the red light there would be consequences, all of which had been collectively predetermined when implementing the five Cs in our community. With the beginning of each session (morning, middle and afternoon) students started afresh and all name tags were moved back to the traffic light starting position.

In previous educational eras, such as throughout my own schooling, the classroom design was built around "chalk and talk". Students sat in rows; often organised in alphabetical order. Children were required to focus on the teacher whose major pedagogic aide at the front of the classroom was the blackboard. The implication of such a classroom was that knowledge sprang only from the teacher and students were considered blank slates. This classroom was not a place that I wanted to revisit.

My training had taught me that this rather rigid view of learning could be altered dramatically. It taught me to see myself less as this type of teacher and more as the scaffolder and enabler of learning, thus changing the design and organisation of my classroom dramatically. In the carefully constructed classroom there is an unspoken curriculum. Not the hidden curriculum that separates and divides students but the shared curriculum that draws students into a community, celebrates learning and recognises excellence. With this in mind, the design and organisation of our learning community was a high priority.

There was a lot more to designing our classroom, the safe haven for our learning community, than rearranging the chairs or purchasing some colourful posters. This room became the cognitive, emotional and ethical canvas for my students-as individuals and as a group. In our design it was important to note the first thing that students and their families encountered when they entered our classroom. I made sure it was always an exhibit of the students' recent work. The design and layout of our classroom assisted to achieve the aim of our learning community, which was at all times for work to flow, with materials being ready and abundant, students feeling safe and an apparent logic to classroom organisation that enhanced learning.

Literacy was of the utmost importance: without this knowledge students will not have the necessary skills to succeed in life. I provided literacy experiences that tapped into the interests of my students. There was always a variety of books so that any student in a spare moment could engage in independent reading. This was my one and only fast finisher literacy activity, reading. Additionally I always kept books, and bookmarks, on my desk so that my students could see the value I placed on literacy and language. As a community we discussed language, manipulated language, and immersed ourselves in language. As a teacher, if I could choose to impart one gift for my students it would always revolve around literacy. I make sure that they see me reading for my own pleasure and that I show my enjoyment when partaking in their shared reading sessions.

Another element of my classroom was my desk! Funny I know, but it is quite noticeable how traditional teachers often like to place their desks front and centre of the classroom. The not-so-hidden message here is "I'm in charge". I am not the least bit naive regarding the need for leadership and behaviour management in the classroom. In my classroom, however, I believe that the leadership must be shared and an emphasis placed on community. I engineered my classroom design backwards, from the point of view of maximising student learning, focusing on communication, reflection and reinforcement rather than miscommunication, rote learning and punishment. I would say that many of the disciplinary problems encountered in classrooms stem, in part, from poorly designed classrooms where students can sometimes feel like an alienated audience rather than an engaged community. A great deal of the difference between classrooms that function and those that function well can be traced back to their level of unity. When students feel safe, welcome and have input into classroom structure, they 'invest' in classmates and procedures.

It is hard to believe I have only been at my school for such a short period of time. I can honestly say that in the past 12 months I have learned how to manage my classroom as a community. (However, the day I stop learning about this is the day I should change professions.) I have come to experience firsthand the many different learning styles among students and the range of personalities that accompany these. I am now armed with a plethora of strategies that assist me in actively engaging this variety within a community-learning environment. I have confronted the realities of the school and, of course, the reality of testing and reporting. I have become a professional educator through my trials but have also been triumphant through successes with my students. 
As a teacher my goal is to be active, assertive and enthusiastic. I treat my classroom as a creative and community-building opportunity. To achieve this I am constantly changing tactics. I am run off my feet turning four walls into a safe haven, a community of learners, and just quietly, I wouldn't have it any other way.

Closing Commentary Statement: Katie's "expose" of her first year of full-time teaching is an inspiring story. Her care for her students is palpable and admirable, but this is matched by her knowledge, skills and competencies. Katie's professional philosophy bells ring through clearly and loudly here, as do the obvious links to her approach to classroom management. You can almost see her classroom management plan poking out between the lines of her story! Positive respectful relationships, focused curriculum and sound, flexible pedagogy weave their way through the paragraphs. Classroom organisation, including clear behavioural standards and thorough attention to the organisation of the physical environment, are also her priorities. The central importance of a focus on learning and the curriculum is explicit. Katie has taken a somewhat pragmatic approach to her classroom management theory and practices, but there remains a clear emphasis on ecological, sociocultural and psychoeducational perspectives. This story is rich in reflection, and evidence of its application as reflexion, but Katie's strong professional philosophy, clearly influenced by her worldview (knowledge and interpretive filters) shines throughout her story. There is little doubt in this reader's mind that "a successful satisfied teacher and students who belong and who are safe, happy and learning" is the most likely happy ending for this story; despite the subtext of struggle and challenge!

\section{Discussion}

In looking back over the ongoing analysis of the abovementioned sample of "Reflections from the field" (and indeed all of the 54 reflections gathered and analysed to date) a range of observations can be made which speak to and offer some explanation for similarities and differences, trends, themes and inconsistencies in the data. The following ten points are highlighted for this paper.

(Note: Word limits only allowed for a very brief description and summary analysis of the extensive data set. The lead author is preparing a "sister paper" which will deliver a comprehensive comparative analysis of all of the data set gathered to date.)

1) Substantial elements of ALL of the stories are entirely reflective of the key elements of the Lyford model, namely it's five principles, four main parts and various sub-parts, categories and storyline. The Model appears to be authentic, comprehensive, relevant, and potentially informative to practicing teachers, notwithstanding their various career stages and diverse teaching contexts.

2) Prior knowledge of the Lyford model does not seem to impact its authenticity and relevance for practicing teachers (as in 1. above), but does correlate with stronger use of the pertinent terminology and metalanguage in the storytelling of those with such prior knowledge.

3) Preservice teachers show a stronger inclination to formally proclaim and explain their theoretical approach to classroom management than do later career stage teachers.

4) More experienced (later career stage) teachers show a stronger inclination to ground their classroom management decision making in their professional philosophy rather than a formally expressed/referenced theoretical approach to classroom management.

5) Preservice and early career teachers explain a greater need for formalising and referring to their classroom management plans to rationalise ("justify") their classroom management decision-making.

6) All teachers emphasised and clearly articulated a focus on positive relationship building with students although the nature of these relationships differed between preschool, primary and secondary contexts; generally reflecting benchmarks around moral, social and intellectual development.

7) Temporary teachers (especially those on shorter term day-by-day appointments) highlighted the need to be (very) well organised and prepared; and generally faced higher levels of challenge around establishing and maintaining classroom environments most conducive to learning.

8) Special education teachers (including those appointed to special classes and those working more in a team teaching role in other's classes) faced relatively unique challenges with respect to classroom management; mostly related to responding to very diverse student challenging behaviours and in working collaboratively with teaching and paraprofessional peers.

9) Full time primary classroom teachers were generally able to describe and explain their one preferred approach to classroom management for their class for any year. Secondary teachers were generally more theo- 
retically eclectic. That is, they "shifted" their approach depending upon the age/developmental level of the class/es they were teaching. Temporary teachers oriented more towards a "pragmatic" behaviourist rather than a psychoeducational theoretical approach to classroom management.

10)All 54 of the (practicing) teachers who gave their classroom management story for publication and analysis were exemplary practitioners. All clearly took "ownership" for their own classroom management planning. In the earlier stories there was very little reference to systemic imperatives but more recent stories (2013 onwards) give emerging reference to school wide behaviour management and student welfare initiatives.

\section{Conclusion}

In short, our continually growing second primary data set (the stories of our classroom teaching colleagues as provided in their reflections and stories from the field) provides clear, substantial and growing evidence for the rigour, authenticity and utility of the Lyford model of classroom management. The first author continues to collect approximately 10 of these stories annually. Two clearly discernable shifts in this data set are evident. First systemic/school wide approaches to student welfare (especially e.g. the "Schoolwide Positive Behaviour Support” approach) are having an emerging impact upon individual teachers' classroom management planning. Second, there are increasing concerns (across all contexts) over demands to manage more challenging individual student behaviours; particularly those arising out of mental health problems.

But what does this mean for our fellow classroom teachers? It is the authors' collective view that the "rise and rise" of systemic/schoolwide strategies for responding to student welfare and teaching issues arising particularly out of student mental health problems is timely and appropriate; notwithstanding that over the last 30 or so years there have been very similar successive and successful "movements" (e.g. Canter \& Canter's Assertive Discipline, Glasser's Control/Choice Theory, Functional Behavioural Analysis, Wragg's Talk Sense to Yourself, Response to Intervention). This behoves teaching professionals to read the contemporary (evidence-based) literature (Beamish \& Bryer, 2012; Odom et al., 2005; O’Neill \& Stephenson, 2014), and to get involved with inservice professional development and learning initiatives in the field.

And what does this mean for our fellow pre-service teacher educators? It is the authors' collective view that we should collaboratively and more proactively lobby Governments for funds to support further research into and study around the social dynamics within classrooms and student classroom management across all teaching/learning contexts. Teaching has become an increasingly challenging profession. Stakes are high with respect to student learning and welfare, and with respect to the professional lives of early (and even later career) teachers. Preservice training in the praxis (theory and practice) of evidence-based classroom management approaches, strategies and techniques is probably more important today than it was a generation ago.

\section{Acknowledgements}

The authors again thank their many ex-students and colleagues who willingly and collaboratively contribute their "Reflections from the field" for publication and analysis.

\section{References}

Anderson, P. L. (2005). Case Studies for Inclusive Schools (2nd ed.). Austin, Texas: Pro-Ed.

Arthur-Kelly, M., Sutherland, D., Lyons, G. S., McFarlane, S., \& Foreman, P. (2013). Enhancing Pre-Service Teachers Education Programs to Support Inclusion: Perspectives from New Zealand and Australia. European Journal of Special Needs Education, 28, 217-233. http://dx.doi.org/10.1080/08856257.2013.778113

Beamish, W., \& Bryer, F. (2012). Co-Researching Best Practice in an Australian Special School: The Process of Participatory Action Research. Special Education Perspectives, 21, 21-33.

Board of Studies, Teaching and Educational Standards (BOSTES) (2014). Classroom Management and Students with Special Education Needs. Sydney: Author.

Bronfenbrenner, U. (1979). The Ecology of Human Development: Experiments by Nature and Design. Cambridge, MA: Harvard University Press.

Brophy, J. (1999). Perspectives of Classroom Management: Yesterday, Today and Tomorrow. In H. J. Freiberg, \& J. E. Brophy (Eds.), Beyond Behaviourism: Changing the Classroom Management Paradigm. Boston: Allyn \& Bacon.

Buchanan, J., Prescott, A., Schuck, S., Ausbusson, P., \& Burke, P. (2013). Teacher Retention and Attrition: Views of Early Career Teachers. Australian Journal of Teacher Education, 38. http://dx.doi.org/10.14221/ajte.2013v38n3.9 
Charmaz, K. (2006). Constructing Grounded Theory: A Practical Guide through a Qualitative Analysis. London: Sage.

Childs, K. E., Kincaid, D., George, H. P., \& Gage, N. A. (2015). The Relationship between School-Wide Implementation of Positive Behaviour Intervention and Supports and Student Discipline Outcomes. Journal of Positive Behaviour Interventions. http://dx.doi.org/10.1177/1098300715590398

Day, C. (1999). Developing Teachers: The Challenges of Lifelong Learning. Bristol: Taylor \& Francis.

Denzin, N. K., \& Lincoln, Y. S. (2000). Handbook of Qualitative Research (2nd ed.). Thousand Oaks, CA: Sage.

Denzin, N. K., \& Lincoln, Y. S. (2005). The Sage Handbook of Qualitative Research. Thousand Oaks, CA: Sage.

Ewing, R., \& Manual, J. (2005). Retaining Early Career Teachers in the Profession: New Teacher Narratives. Change: Transformations in Education, 8, 1-16.

Flick, U. (2005). An Introduction to Qualitative Research. London: Sage.

Flick, U., Von Kardoff, E., \& Steinke, I. (2004). What Is Qualitative Research? An Introduction to the Field. In U. Flick, E. Von Kardoff, \& I. Steinke (Eds.), A Companion to Qualitative Research (pp. 3-12). London: Sage.

Foreman, P. (2014). Chapter 1, Introducing Inclusion in Education. In P. Foreman, \& M. Arthur-Kelly (Eds.), Inclusion in Action (4th ed., pp. 1-9). South Melbourne: Cengage Learning.

Godfrey-Smith, P. (2003). Theory and Reality: An Introduction to the Philosophy of Science. Chicago, IL: University of Chicago Press.

Gore, J., \& Parkes, R. (2008). On the Mistreatment of Management. In A. Phelan, \& J. Sumsion (Eds.), Critical Readings in Teacher Education (pp. 45-60). New York: Sense Publishing.

Grundy, P. (1995). Action Research as Professional Development. Occasional Paper \#1, Perth: Murdoch University. Innovative Links between Universities and Schools for Teacher Professional Development: A National Professional Development Project.

Henley, M. (2006). Classroom Management: A Proactive Approach. Upper Saddle River, NJ: Pearson Merrill Prentice Hall.

Jones, V. F., \& Jones, L. S. (2013). Comprehensive Classroom Management: Creating Communities of Support and Solving Problems. Sydney: Allyn and Bacon.

Killen, R. (2012). Effective Teaching Strategies: Lessons from Research and Practice (4th ed.). Melbourne: Social Science Press.

Kounin, J. S. (1970). Discipline and Group Management in Classrooms. New York: Holt, Rinehart and Winston.

Ladwig, J. G. (2009). Working Backwards towards Curriculum: On the Curricular Implications of Quality Teaching. The Curriculum Journal, 20, 271-286.

Lyons, G. S., Ford, M., \& Arthur-Kelly, M. (2011). Classroom Management: Creating Positive Learning Environments (3rd ed.). South Melbourne: Cengage Learning.

Lyons, G. S., Ford, M., \& Slee, J. (2014). Classroom Management: Creating Positive Learning Environments (4th ed.). South Melbourne: Cengage Learning.

Manning, M. L., \& Bucher, K. T. (2013). Classroom Management: Models, Applications and Cases (3rd ed.). Upper Saddle River, NJ: Pearson Education.

Michail, S. (2011). Understanding School Responses to Students' Challenging Behaviour: A Review of the Literature (Research Paper \#5). Sydney: UnitingCare, Children, Young People and Families.

Newman, F. M., \& Associates (1996). Authentic Achievement: Restructuring Schools for Intellectual Quality. San Francisco, CA: Jossey-Bass.

O’Neill, S. C., \& Stephenson, J. (2014). Evidence-Based Classroom and Behaviour Management Content in Australian PreService Primary Teachers' Coursework: Wherefore Art Thou? Australian Journal of Teacher Education, 39, Article 1.

Odom, S. L., Brantlinger, E., Gersten, R., Horner, R. H., Thompson, B., \& Harris, K. R. (2005). Research in Special Education: Scientific Methods and Evidence-Based Practices. Exceptional Children, 71, 137-148.

Porter, L. (2007). Student Behaviour: Theory and Practice for Teachers (3rd ed.). Crows Nest, NSW: Allen \& Unwin.

Shulman, L. S. (1992). Towards a Pedagogy of Cases. In J. H. Shulman (Ed.), Case Study Methods in Teacher Education (pp. 1-30). New York: Teachers College Press. 